This item was submitted to Loughborough's Research Repository by the author.

Items in Figshare are protected by copyright, with all rights reserved, unless otherwise indicated.

\title{
Understanding the critical success factors for delivery of megaprojects in Colombia
}

PLEASE CITE THE PUBLISHED VERSION

https://doi.org/10.1680/jmapl.17.00005

\section{PUBLISHER}

C ICE Publishing. Published by Thomas Telford

\section{VERSION}

AM (Accepted Manuscript)

\section{PUBLISHER STATEMENT}

This work is made available according to the conditions of the Creative Commons Attribution-NonCommercialNoDerivatives 4.0 International (CC BY-NC-ND 4.0) licence. Full details of this licence are available at: https://creativecommons.org/licenses/by-nc-nd/4.0/

\section{LICENCE}

CC BY-NC-ND 4.0

\section{REPOSITORY RECORD}

Cepeda, Deisy M., M. Sohail, and Olufemi O. Ogunlowo. 2019. "Understanding the Critical Success Factors for Delivery of Megaprojects in Colombia". figshare. https://hdl.handle.net/2134/28093. 


\section{Accepted manuscript \\ doi: 10.1680/jmapl.17.00005}

\section{Accepted manuscript}

As a service to our authors and readers, we are putting peer-reviewed accepted manuscripts (AM) online, in the Ahead of Print section of each journal web page, shortly after acceptance.

\section{Disclaimer}

The AM is yet to be copyedited and formatted in journal house style but can still be read and referenced by quoting its unique reference number, the digital object identifier (DOI). Once the AM has been typeset, an 'uncorrected proof' PDF will replace the 'accepted manuscript' PDF. These formatted articles may still be corrected by the authors. During the Production process, errors may be discovered which could affect the content, and all legal disclaimers that apply to the journal relate to these versions also.

\section{Version of record}

The final edited article will be published in PDF and HTML and will contain all author corrections and is considered the version of record. Authors wishing to reference an article published Ahead of Print should quote its DOI. When an issue becomes available, queuing Ahead of Print articles will move to that issue's Table of Contents. When the article is published in a journal issue, the full reference should be cited in addition to the DOI. 


\section{Accepted manuscript \\ doi: 10.1680/jmapl.17.00005}

Submitted: 31 January 2017

Published online in 'accepted manuscript' format: 08 December 2017

Manuscript title: Understanding the Critical Success Factors for Delivery of Megaprojects in

Colombia

Authors: Deisy M. Cepeda ${ }^{1}$, M. Sohail ${ }^{2}$, Olufemi O. Ogunlowo ${ }^{3}$

Affiliations: ${ }^{1}$ School of Civil and Building Engineering, Loughborough University, Loughborough, Leicestershire, LE11 3TU, United Kingdom. ${ }^{2}$ School of Architecture, Building and Civil Engineering, Loughborough University, Loughborough, Leicestershire, LE11 3TU, United Kingdom. ${ }^{3}$ Strategic Outsourcing Limited, Lagos, Nigeria.

Corresponding author: Olufemi O. Ogunlowo, Strategic Outsourcing Limited, Lagos, Nigeria. Tel.: +2348022234055

E-mail: femio@solnigeria.com 


\section{Accepted manuscript \\ doi: 10.1680/jmapl.17.00005}

\section{Abstract}

By their very nature, megaprojects have significant short- and longer-term impacts on the socio-economic, technical, environmental and political landscape of the host country, but many are delivered with time and cost overruns and sometimes with quality discrepancies. This paper examines the critical success factors for megaprojects in Colombia - from the project definition stage to successful handover - from the perspective of professionals involved in the delivery of megaprojects in that country. It applies a mixed approach of quantitative and qualitative data collection and analysis to rank 34 factors identified in literature sources as being critical to the success of megaprojects. Analysis shows that inadequate information at the tender stage, design changes during the construction phase, and limited availability and supply of materials have had a major negative influence on the delivery of megaprojects in Colombia. In contrast, adverse weather conditions and lack of prior experience with similar projects have had the least impact. This paper recommends approaches to mitigate the risks associated with the factors investigated. 


\section{Accepted manuscript \\ doi: 10.1680/jmapl.17.00005}

\section{Introduction}

In the 1990s, the US Federal Highway Administration defined megaprojects as large-scale projects with a budget over 1 billion US dollars (Richard, 2006). Since then, the term has been adopted for large infrastructure projects costing more than US\$1 billion. However, more recently, rather than using a monetary threshold only, many scholars have also used features to define megaprojects. In particular, Bruzelius et al. (2002) defined a megaproject to be any project that has a cost of delivery over US $\$ 1$ billion, a building time of more than five years, a life expectancy of over 50 years, high uncertainty over possible usage and cost estimations, and a large indirect and immeasurable benefit to a number of parties. Besides, many other scholars have used much broader descriptions; among these are Altshuler and Luberoff (2003) who characterised megaprojects as initiatives that are physical, costly and public in nature; Li and Guo (2011) who noted that they are challenging projects which involve a complex interplay of technology, millions of working hours, many stakeholders and high public attention; and Flyvbjerg (2014) who described them as unique, ambitious "trait making" infrastructures designed to change the structure of the society. Megaprojects occur in diverse sectors including scientific endeavours such as the Large Hadron Collider (the world's largest and most powerful particle accelerator), large-scale transportation infrastructures and energy exploration in inhospitable seas. As observed by Mišić and Radujković (2015), it might be impossible to find two megaprojects that are identical.

There is sufficient evidence that megaprojects often experience considerable delivery delays and budget overruns, while at the same time failing to achieve their initial objectives 


\section{Accepted manuscript \\ doi: 10.1680/jmapl.17.00005}

(see Aziz, 2013). Examples of notable megaprojects across the world that experienced these problems include:

- The Central Artery/Tunnel Project in Boston, USA, which was completed in 2007 at the cost of more than US\$14.6 billion against scheduled completion in 1998 at an estimated cost of US $\$ 2.8$ billion. This was in addition to technical shortcomings, design flaws and professional misconduct of project managers (see TRB, 2003)

- The Alberta Mega Oil Sands Projects in Canada, which ranged between 8 billion Canadian dollars $(\mathrm{C} \$)$ and $\mathrm{C} \$ 14$ billion in terms of capital investment. These were reported by Jergeas (2008) to have mostly experienced cost overruns by up to $100 \%$ of the original cost estimates.

- The Channel Tunnel Rail Link in the UK, which experienced a four-year delay and a $57 \%$ budget overrun. It was completed in 2007 at a cost of 9.63 billion Great British pounds (£), as reported by Dimitriou et al. (2013).

Here, the focus is on Colombia, a country that has launched an ambitious infrastructural development plan during the last decade. The country's Intermodal Transportation Master Plan 2015-2030 has a US\$70 billion initial budget and an annual investment of US\$10.4 billion to 2035 to develop over $20,000 \mathrm{~km}$ of roads, more than $1,600 \mathrm{~km}$ of new railway, over $5,000 \mathrm{~km}$ of waterways, as well as 31 airport expansions and port development projects (see The WorldFolio, 2016). In addition to this, the country has completed and ongoing megaprojects in many sectors of the economy, some of which are highlighted in Table 1. 


\section{Accepted manuscript doi: 10.1680/jmapl.17.00005}

Public records indicate that the three operational projects listed in Table 1 have experienced time and cost overruns. For example, the Reficar Modernization and Expansion Project experienced a delay of 21 months and a total cost of US\$8,016 billion - more than double of the original estimate of US $\$ 3.78$ billion (BNamericas, 2016). As reported by Semana (2016), the client, Ecopetrol - formerly known as Empresa Colombiana de Petróleos S.A. blamed the delay on poor project planning by the main contractor and pressed for compensation of US\$2 billion, whereas the main contractor attributed the delay to changes in the scope of work which required design changes during the construction process, labour issues such as strikes and extreme weather conditions. However, the independent report of Colombia's Comptroller General ascribed both the delays and cost overrun to deficient control and supervision by the client and the project consultants at the initial stages, as well as the limited experience of the main contractor with respect to the design, procurement and construction of similar projects (see Pinzon et al. (2015 cited in Cepeda, 2016, p.35).

Many studies have been conducted to identify possible reasons for, and issues contributing to, time and cost overruns in projects generally and megaprojects in particular. Anderson et al. (2006) noted that the factors driving the escalation of a project cost may occur at any stage in the project cycle, but are more noticeable in the execution phase. This is especially due to public interest and spotlight on the project during this phase. Shehu et al. (2014) attributed key challenges in the execution phase to changes in the scope of work from the client, low speed in decision-making from management and inadequate site supervision. Merrow (2011) in his work on industrial megaprojects identified seven pitfalls, which we have 


\section{Accepted manuscript doi: 10.1680/jmapl.17.00005}

characterised as: i) inequitable distribution of project benefits; ii) unwarranted speed of delivery; iii) insufficient attention to detail at the initial stages; iv) inadequate attention to front-end activities; v) arbitrary cost-cutting; vi) dumping of project risk on the contractor; and vii) passing the buck. Nonetheless, a megaproject that presents delays and cost overrun may still generate positive outcomes for the stakeholders, and vice-versa. This suggests a clear distinction between the success of a project and that of project management, a view that has been advanced by many authors and is aptly reported by Yong and Mustaffa (2017). In the present article, the focus is on the success of project management.

The present authors note that there was no agreement on the causes of the time and cost overruns in the three main reports that examined the Reficar Expansion Project, the largest megaproject so far in Colombia, and that despite the preponderance of literature, the factors that contribute to the success of a project may differ between countries - as observed by Yong and Mustaffa (2012). Yet, research specific to Colombia is sparse. Furthermore, a review of the literature indicates that many of the country-specific studies on time and cost overruns on projects in general and megaprojects in particular have applied flawed analytical approaches. In many respects, while the variables have been rightly measured using nominal and ordinal scales - which allow for qualitative classification of variables, but cannot quantify - they have been wrongly subjected to inferential statistics, which implies the adoption of materialistic or realist ontology and a positivist or empirical epistemology to qualitative data. For example, Ejaz et al. (2013) who studied megaprojects in Pakistan and Locatelli et.al (2014) who examined 


\section{Accepted manuscript doi: 10.1680/jmapl.17.00005}

megaprojects in the European Union (EU) wrongly applied the coefficient of determination and Fisher exact test respectively to nominal and ordinal data in their studies.

Therefore, the purpose of this research is twofold: first is to identify the factors that are critical to the success of megaprojects in Colombia; and second is to demonstrate an appropriate analytical approach to nominal and ordinal data - where numerical value is attached to world labels, but the scale cannot quantify.

In addition to this introduction (Section 1), the remainder of the paper comprises: Section 2, which outlines the methodological approach; Section 3, which discusses the results; Section 4 highlighting the implications for practice and potential applications; and Section 5 presenting the conclusions.

\section{Methods}

\subsection{Research design}

Following the aim of the study, the primary research question was: 'Which factors have the most influence on the completion of megaprojects in Colombia?' Both the research question and the aim fit into the hermeneutic understanding category of research purpose (see Willis, 2007) and lend themselves to the application of a qualitative enquiry approach with interpretive epistemology and necessitate the use of a descriptive conceptual framework that links to the research objectives.

The present study employed the theoretical underpinning of management of projects (MoP) advocated by Morris (1994), which places greater emphasis on the project definition phase. This is as opposed to the project management approach, widely attributed to Cleland 


\section{Accepted manuscript \\ doi: 10.1680/jmapl.17.00005}

and King (1968), which rely on the tools and techniques approach to project management. The MoP Framework, developed from the work of Morris (2013) by Pinto and Winch (2015), indicates that successful delivery is dependent on critical organisational capabilities in the major functions - including strategy and finance, technology, commercial arrangements and the alignment of people and structures. It further shows that success in the project delivery (the execution) phase requires more than the management of time, cost and quality - the three traditional criteria for measuring the execution phase of a project; rather it also requires the management of integration, human resources, communication and procurement.

Considering the first objective of the study, the authors reviewed literature sources to identify a suitable definition for 'critical success factors' (CSFs). The review of literature indicated that while many definitions of the term are available, especially as it has found application in many disciplines, the definitions that relate to projects mostly conform to the project management approach. Nonetheless, the search indicated that the core of the definitions was consistent across disciplines. Examples of the definitions considered relevant to this study include Baccarini and Collins (2003), who described CSFs as a set of circumstances, facts or influences which contribute to the outcome of a project; Howsawi et al. (2014), who defined it as the factors that can contribute and influence the success of a project; and Alias et al. (2014), who defined it as the conditions or variables that can lead to the success of a project. However, considering the MoP theoretical underpinning of this study, the present authors define CSFs as the factors that can significantly influence the success of the delivery of megaprojects in the entire project lifecycle, from project definition to successful handover. 


\section{Accepted manuscript \\ doi: 10.1680/jmapl.17.00005}

The descriptive conceptual framework comprised four elements, to: i) identify the factors contributing to time and cost overruns on megaprojects; ii) rank the identified factors from the perspective of stakeholders who have been involved in the delivery of megaprojects in Colombia; iii) confirm the ranking of the factors; and iv) provide recommendations for future experiences. Consistent with Denzin (1970), a mixed research method was deemed most appropriate and the explanatory method (see Creswell, 2003), which involved a sequential quantitative and qualitative data collection process, was applied.

The methodology adopted is presented retrospectively in Sections 2.2 to 2.6, below.

\subsection{Identification of the factors investigated}

Considering the availability of sufficient, credible and reliable information in the literature, the study identified the factors investigated from secondary sources - including academic literature, published reports, online sources and grey literature, which comprised government publications and reports, newsletters, working papers, technical reports and conference proceedings. From this process, 126 factors were identified; however, further analysis of the taxonomy showed some to be synonyms and interchangeable, while others were a mixture of features embedded within the functional and descriptive categories. For example, Anderson et al. (2006) listed market conditions and the effect of inflation as separate factors, while the present authors argue that the latter is a consequence of the former. Thus, the factors were reclassified using a four-stage linear process that involved identification, functional aggregation, labelling and domiciliation, where 'domiciliation' refers to the location of each factor in line with the observation of Sanvido et al. (1992) that success factors can be internal 


\section{Accepted manuscript doi: 10.1680/jmapl.17.00005}

or external. Consequently, the 126 factors were reclassified into 34 and grouped into nine categories based on the predominant themes through which they could be meaningfully organised, interpreted and presented. Although corruption was among the factors identified in the literature, the authors deliberately did not include it among the factors surveyed because it was perceived that questions on corruption might cause the respondents to be less responsive to the survey.

Table 2 presents the factors, their categories and locations where only the unique factors are numbered for ease of reference, but the order of appearance and numbering does not confer any level of influence at this time. An in-depth look at these factors suggested that they may apply to projects irrespective of size, scope, cost, duration of execution or any other project features. This potentially makes the findings of this study of more general application.

\subsection{Study sample}

As noted by Maylor and Blackmon (2005), population sampling for the purpose of qualitative research designs should be characterised and represented by concepts of gaining deeper knowledge and understanding of the study groups' perceptions of the subject of research. Hence, a non-probability (purposive) sampling method was considered most appropriate among the wide range of sampling techniques identified in the literature sources. In particular, the homogeneous sampling method was deemed most suitable and was selected as the study was not a test of a hypothetical generalisation and did not intend to seek relationships that may establish scientific laws. In addition, the research question was specific to the characteristics of the particular group of interest and the method achieves a sample whose units share the same 


\section{Accepted manuscript \\ doi: 10.1680/jmapl.17.00005}

or close characteristics or traits: in this instance, construction professionals who have been involved in megaprojects. Hence, the homogeneous criterion used was involvement at a senior level in megaprojects in Colombia.

The participants were identified through a formal and an informal process. The formal process was the principal avenue for the identification of participants, as it generated nearly $90 \%$ of the study sample. It involved a request for participation to the 124 key personnel of the construction companies involved in megaprojects in the country. The informal process involved the use of social media platforms, mainly LinkedIn and Facebook, to identify professionals who might have had experiences with the delivery of megaprojects in the country; this process identified 13 professionals. Overall, these processes yielded 137 professionals, who constituted the study sample. The profiles of the eventual participants are presented and discussed in Section 3.

\subsection{Questionnaire design}

The design of the questionnaire involved conceptualisation, testing and revision. The conceptualisation was an iterative process that focused on clarity of the question, selection of appropriate scales of measurement and matching to analytical methods. Testing comprised an independent review of the questionnaire to assess the extent to which it was viewed as covering the concept it purported to measure ('face validity') and the degree to which it measured the variables intended ('construct validity'). Testing also included a pilot test which employed the test-retest reliability field-test method. The revision stage involved modification of both the form and content of questions based on the feedback received from the pilot sample. 


\section{Accepted manuscript \\ doi: 10.1680/jmapl.17.00005}

BOS online survey tool was used to design the questionnaire, and this used a combination of categorical and rating questions. The categorical questions aided the identification of the respondents and were measured by nominal scales that enabled demographic analysis. The rating questions allowed participants to compare the variables based on a unipolar ordinal scale that measured the severity of the influence of the factors investigated.

Considering the second objective of the study, the authors observe that the distinction between ranking and rating questions is that rating allows for qualitative classification of variables but cannot quantify, while ranking measures and orders relative quality represented by the variables but does not necessarily represent equal intervals. Rating thus allows for comparison of a variable to itself on a scale, while ranking uses ipsative measures that force respondents to relatively order the variables under investigation.

It should be noted that this study did not employ ranking questions because of the large number of variables studied (34), but instead derived the ranking from the rating of the participants. Table 3 shows the composition, objective, type and measurement scale for each question.

\subsection{Data collection}

As stated in Section 2.1, data collection took place in two sequential stages. First, data was collected through questionnaires and second, data was collected using semi-structured interviews among the most experienced respondents.

The questionnaire was distributed to study participants electronically in English and Spanish, via email, LinkedIn and Facebook; this method lowered the cost of survey 


\section{Accepted manuscript doi: 10.1680/jmapl.17.00005}

administration and guaranteed prompt delivery and receipt. In addition, it eliminated geographical limitations at times when the researchers were not physically present in Colombia. The questionnaire included an information sheet on the study purpose and the contact details for any question or additional information the respondent might require. The respondents had four weeks to complete and return the survey.

The interview method was chosen for the second stage and was designed as a validation process for the findings of first stage. This is because the interview method offers confidentiality, which was considered crucial as it was anticipated that data might include information on potentially sensitive project-specific issues. The person-to-person semi-structured form of interview was used because of its flexibility and the opportunity it presents to the researcher to probe for more in-depth insights from the narratives of the respondent and to seek information that may not have been previously anticipated. The study addressed the main limitations of the method - which include the possibility of implicit and explicit bias, the potential inability of the interviewee to accurately recall specific details of events, and the possible imposition of preconceived ideas - through enquiries and the application of the principles of consistency (cross-checking each interviewee's testimony with other participants) and verifiability (cross-checking each interviewee's testimony with available public documents). Each interview lasted an average of one hour, and was tape recorded and subsequently transcribed. The interview plan included the ten secondary, broad, open-ended questions derived from the analysis of the questionnaires. Each interview was analysed before the subsequent one, and this allowed for the application of emerging insights 


\section{Accepted manuscript \\ doi: 10.1680/jmapl.17.00005}

in subsequent interviews.

\subsection{Data analysis}

Analysis of the data generated through the survey employed the use of descriptive statistics, including a set of percentages and measures of central tendency, as the variables measured were nominal and ordinal data and did not support the use of parametric analysis as the measurement scales allow for qualitative classification of variables only (they cannot quantify). For ease of analysis, the world labels on the unipolar ordinal scale were assigned scores as follows Minimum Influence $=1$, Medium Influence $=2$, Strong Influence $=3$, and Extreme Influence $=4$. The assigned numbers are ordinal and were used strictly for qualitative classification of variables only (they could not quantify). Nonetheless, this enabled the application of the 'mean score' - MS, which conveys no statistical meaning, as the measurement scale is ordinal - to rank the factors.

$$
\text { Here, } \mathrm{MS}=\frac{\sum(f \times S)}{N}(1 \leq \mathrm{MS} \leq 4)
$$

where $\mathrm{f}, \mathrm{s}$ and $\mathrm{N}$ represent the frequency of responses, respondents' score for each factor and the total number of responses, respectively.

This method has been used in similar studies, such as Chan and Kumaraswamy (1996), and is one of the most appropriate methods available for the analysis of ordinal data derived from rating questions. It is important to note that inferential statistical methods - such as the Chi square test for independence, the McNemar change test, the Wilcoxon matched-pairs signed-ranks test, the intra-class correlation coefficient, kappa statistics, Spearman's rank-order 


\section{Accepted manuscript \\ doi: 10.1680/jmapl.17.00005}

correlation coefficient, Kendall's W coefficient of concordance, t-statistics and F-tests - are not applicable to ordinal-scaled variables. It is also generally accepted that parametric statistics are applicable to interval and ratio data that conform to a normal distribution (see Riley et al., 2000). Hence, consensus measurement for rating questions fits to the use of qualitative analysis and descriptive statistics. Prominent statistical analyses for ranking questions are measures of central tendency, rank order correlation, frequency distributions and non-parametric analysis of variance (see Hill and Fowles, 1975; and Hasson et. al., 2000). There are three significance tests for cases involving more than two dependent samples, namely: the Friedman test (also known as the Friedman two-way analysis of variance), which is the significance test for more than two dependent samples and is used to test that there is no significant difference between the size of a dependent sample and the population from which it is drawn; Kendall's coefficient of concordance (W) test, which is a measure of the agreement among several judges who are assessing a given set of objects; and Cochran's Q test, which is used to test whether or not the part of a given variable is the same across multiple dependent samples.

This study did not employ ranking questions because of the large number of variables studied (34), but instead derived the ranking from the rating of the participants.

The analysis of the data collected using semi-structured interviews involved hermeneutics analysis premised on the theory of interpretation and achieving an understanding of texts and utterances, as described by Patterson and Williams (2002, pp.47-49). This method allows themes to emerge from data and promotes a holistic understanding. It also shows the inter-relationships among themes, while at the same time enabling individual themes to retain 


\section{Accepted manuscript \\ doi: 10.1680/jmapl.17.00005}

rich characteristics. The data analyses were conducted at the individual level (idiographic) and across individuals (nomothetic).

\section{Results and discussion}

\subsection{Quantitative survey}

Fifty-three responses were received out of the 137 questionnaires distributed, but only 48 responses were valid. This represented an effective response rate of $35 \%$ and was within the anticipated range (see Callegaro et al., 2015). The distribution of the respondents, shown in Table 4, is expressed as percentages only to gain an understanding and not to make statistical inferences. As seen in the table, a majority (64\%) of the respondents had over four years' experience with megaprojects, and this offers an advantage for the quality of data - especially as megaprojects are recent in Colombia and thus four years' experience is contextually significant. In addition, the nearly $20 \%$ of respondents that came from the planning, design and engineering professions was considered a great advantage, as megaprojects in Colombia have been awarded to international companies who have undertaken the early stages of the projects outside of Colombia. For example, the contractor for the Reficar Modernization and Expansion Project conducted detailed engineering and procurement out of Houston, USA. Furthermore, this explains why nearly $75 \%$ of respondents were site supervisors, control officers or allied professionals.

Although the distribution of the respondents was skewed to oil and gas, both the response rate and the distribution of respondents satisfied the goal of the study as the response rate was within the anticipated range and the participants broadly represented the purposive sample 


\section{Accepted manuscript doi: 10.1680/jmapl.17.00005}

given that two of the three operational megaprojects in the country are in the oil and gas sector. The likely impact of the respondents' profiles is discussed in Section 3.3, while the results are presented in a table format in Tables 5 to 8 and discussed in this section and Section 3.2.

As shown in Table 5, most of the respondents' opinions fall within two adjacent points, suggesting a convergence of views. This further indicates that the factors ranked as 1 in every category recorded a mean score greater than 3, indicating that each of the categories investigated has a 'Strong Influence' on the delivery of megaprojects. Table 5 indicates that design changes during the construction phase and the availability of materials jointly ranked as the most critical success factors, each with a mean score of 3.44 and with nearly all the respondents' opinions (92\%) falling on the adjacent points of 'Strong Influence' and 'Extreme Influence' on the measurement scale.

As seen in Table 6, among the 34 factors investigated, 29 recorded a mean score greater than 3, suggesting that these factors have 'Strong Influence', while others recorded mean scores that were between 2.67 and 2.92, indicating 'Medium Influence'.

Whereas the top-five factors fall into only three categories, four of the bottom five are in the project characteristics category, which - as seen in Table 7 - is the only category with a mean score less than 3 .

As seen in Table 8, there are six internal factors exclusive to the planning phase among which adequacy of tender information and realistic cost estimates, which both had overall ranks of 5 and 6 respectively, have the top-two ranks while appropriate risk assessment had the lowest rank. Nonetheless, all six factors have a mean score between 3.21 and 3.40, suggesting 


\section{Accepted manuscript \\ doi: 10.1680/jmapl.17.00005}

that these factors have 'Strong Influence'. All the factors exclusive to the execution phase comprising of nine internal and 3 external factors have 'Strong Influence' as they recorded a mean score range of 3.44 to 3.04 , with design changes during construction, an internal factor jointly ranked as number 1 along with availability of materials, an external factor. Eight internal factors are common to both the planning and the execution phases and, among them, management strategy, with an overall rank of 3, has the top rank. This result suggests that the management strategy is critical in both phases of a megaproject and supports the MoP Framework developed by Pinto and Winch (2015).

Based on our reclassification, there is no strict external factor in the planning phase. However, there are three in the execution phase and eight that are common to both the planning and execution phases. The availability of materials, with a joint overall rank of 1 , has the topmost rank - suggesting that both internal and external factors have a significant influence on project delivery. The two factors that are present both internally and externally are also common in both the planning and execution phases. These factors, availability of skilled labour and transparency and trust, both recorded a mean score greater than 3, which suggests that they both have a Strong Influence.

The results of the quantitative survey suggest that the technical competence and the managerial ability of the project leadership team, as well as the organisation stability, rather than the physical attributes and conditions of a megaproject, have a higher level of influence on successful delivery. These findings are supported by Lopez and Shane (2014), who identified early agreement with the community and local authorities, identification of the cultural and 


\section{Accepted manuscript \\ doi: 10.1680/jmapl.17.00005}

socio-political circumstances and public outreach efforts as the key factors for the success of the Highway Durango-Mazatlan Projects (Mexico); and Hauswirth et al. (2004), who observed that earlier planning, procurement strategies, the involvement of the community and authorities in the feasibility phase, and a constant information update on the construction process were important factors in the delivery of the Transportation Expansion Project: T-REX (US) project, which took place two years earlier and within budget. The findings are further supported by the observation of Jergeas and Ruwanpura (2010) that the Alberta Mega Oil Sands Projects recorded both cost and time overruns due to an underestimation of the complexity, unrealistic schedules and budget, misaligned project management, misdirected execution, and weak interaction between the planning, budgeting and operations processes. Contrary to the observation by Haidar and Ellis (2010) that the long duration of megaprojects increases complexity and the possibility of variations in social, political, economic, technologic and environmental aspects surrounding the project, the duration of the project ranked last.

\subsection{Semi-structured interviews}

Three interviews that that formed the empirical text for analysis were conducted with senior professionals who were involved in the project control, construction management and project management of the Reficar Modernization and Expansion (oil and gas), Ituango Hydro (power generation) and Ruta del Sol Highway projects respectively. These interviews were designed to validate the findings of the survey, especially the relative importance of the success factors. As stated in Section 2.5, the interview plan included the ten secondary, broad, open-ended questions derived from the analysis of the questionnaires. These were: (1) Which three factors 


\section{Accepted manuscript doi: 10.1680/jmapl.17.00005}

were the most critical for delivering the megaproject you were involved with? (2) Are there factors that are not listed in the 34 investigated, but which you consider critical? (3) Does the result of the study reflect your opinion on the ranking of the CSFs? (4) Both design changes during construction and availability of materials jointly ranked first in the analysis; how do you rank these two? (5) Which party predominantly causes the design changes during the construction phase? (6) How can design changes be better controlled? (7) What are the specific concerns with transparency? (8) What are the project complexities in the context of projects in Columbia? (9) Were there any unintended consequences that occurred on the projects you were involved with? and (10) Were there any major external occurrences that interfered with the success of the project you were involved with?

Each interview was analysed before the subsequent interview in order to apply emerging insight, and to cross-check the interviewee's testimony with previous interviews and public documents for consistency and verifiability. Where necessary, follow-up interviews were conducted via telephone. The interviewers were presented with the survey results after answering the first question (1). This eliminated the possibility of bias and enabled confirmation of the results. For a proper contextual understanding of the narratives of the interviewees, the authors note that they were involved with projects that experienced both time and cost overruns. Analysis showed that the views expressed by the respondents were consistent with the results of the survey.

When asked which three factors were the most critical for delivering the megaproject they were involved with, the first respondent identified inadequate planning at the earlier 


\section{Accepted manuscript doi: 10.1680/jmapl.17.00005}

stages and incomplete information from the client; the second respondent identified lack of a good relationships between stakeholders and inadequate quality and experience on the part of both the project team and subcontractors; while the third respondent mentioned inadequate information at the tender stage and too many changes in the design and specifications. These findings align with Miller and Hobbs (2009), who noted that proper planning at the start of the project, which recognises and takes into consideration potential turbulence, could align projects with organisational strategy, especially when the project is being undertaken by a heterogeneous entity. On further enquiry, the first respondent confirmed that inadequate planning during the early stages reflected poor management strategy at the planning phase. Analysis revealed the factors stated by the interviewees to be in the top five of the ranks from the results of the quantitative survey. This outcome is supported by the World Bank (1996), which concluded that projects with adequate or better identification, preparation and appraisal had an $80 \%$ success rate, against $25 \%$ for projects that were deficient in all these aspects, and that thoroughness during the planning phase had a significantly higher influence on project success than key country macroeconomic variables, external factors or government considerations.

When presented with the outcome of the quantitative survey and asked if it reflected their views, the three respondents unanimously answered in the affirmative. They opined that a lack of information in the early stages of a project is linked to design changes during the construction phase. They expressed the view that changes in technology, unanticipated changes in regulation, stakeholder demands and considerations, difficulty in the actualisation of the 


\section{Accepted manuscript \\ doi: 10.1680/jmapl.17.00005}

original design based on engineering complexities and/or cost considerations, and 'scope creep' were among the key factors that necessitated design changes, and that the availability of materials and their supply had an extreme influence on a project's success. When asked specifically which of the factors investigated had the greatest impact on cost, each of the respondents identified the same three issues: clarity and completeness of the scope of work at the tender stage, a realistic budget and appropriate cost control.

Although the questionnaire deliberately excluded corruption, the interviewees identified this as an endemic and intractable hazard that cut across the fabric of the society and which may be difficult to eliminate. They thus recommended that appropriate government authorities must act to control corruption. In addition, the interviewees suggested the need for adequate control and early and timely supervision by relevant government agencies, including the use of auditable planning procedures as a tool to prevent unwarranted claims by the contractor at any time in the project life cycle, but particularly after project completion, and also to ensure early engagement and accuracy of the cost and schedule. They further expressed the view that risk analysis must start at the planning phase and project risks must be shared transparently and responsibly among key parties at every stage. They unanimously agreed that a multi-disciplinary project management team had a better chance of delivering a project successfully than one that solely comprised engineering experts.

While transparency and trust were seen to be a challenge from the accounts of the interviewees, corruption also emerged as a key contributory factor to the delay and cost overruns of megaprojects in the country. Nonetheless, the authors note that this might not be 


\section{Accepted manuscript doi: 10.1680/jmapl.17.00005}

peculiar to Colombia, as Ahmed and Othman (2013) observed that megaprojects tend to be associated with issues related to corruption because of their large scale, the number of stakeholders, different interests in the economic, political and social environments, and because of their duration. Furthermore, Kenny (2007) noted that the complexity of the construction industry, non-standard production processes and the close relationships between government and other stakeholders are some of the factors that contribute to corruption in construction.

Research participants in the present case identified key complexities specific to Colombia as being the protracted time for rights of way acquisition, delays in environmental licensing and difficulties in securing financing. While recent changes in legislation through the passage of Law No. 1,682 in 2013 were intended to facilitate and expedite the land acquisition process, the reallocation of utilities and speedy environmental licensing, difficulties in attracting financing remain as only 6 out of 30 concessions awarded by the Colombian government since 2013 have been able to secure financing and have advanced to the construction phase (See S\&P Global, 2017). These findings and ongoing complexities bring to the fore the issue of the governance regime. Miller and Hobbs (2005) highlighted the design criteria that should be brought to bear when developing a governance regime for a megaproject and these are consistent with the outcomes of the studies on the Highway Durango-Mazatlan projects and T-REX (US) megaprojects.

Overall, the interviews fulfilled the intended objective as they enabled confirmation of the results of the quantitative survey. 


\section{Accepted manuscript doi: 10.1680/jmapl.17.00005}

\subsection{Research limitations}

Whereas the quality of responses - rather than the number of participants - is the true measure of the outcome of qualitative research, the dominance of the oil and gas sector in the demography of respondents was a limitation. Nonetheless, this situation did not have any adverse effects on either the quality of the data or the outcome of the analysis, which did not call for the expert panel to comprise representative samples for statistical purposes. However, it was possible that certain factors such as personal bias that could not be controlled for by the researchers influenced some of the views expressed. Moreover, unlike experimental studies or studies conducted with control groups in a laboratory, all the subjects who participated in this research were susceptible to external stimuli from diverse sources outside the control of the researchers.

\section{Conclusion}

While cost or time overruns or substandard quality outcomes are not desirable in a project, they become more troubling with megaprojects where delays and cost escalations may have far-reaching effects beyond the reputational risk for the companies involved, maybe threatening the socio-economic, technical, environmental and political systems of the contracting principal. This research aimed at understanding the challenges encountered in delivering megaprojects in Colombia - from the project definition stage to successful handover - with a view to providing industry practitioners in the country with the ability to be more effective and efficient in the management of future megaprojects. 


\section{Accepted manuscript doi: 10.1680/jmapl.17.00005}

While 29 of the factors investigated had a 'Strong Influence' on the success of megaprojects, the study found that an internal factor, 'design changes during construction', and an external factor, 'availability of materials', both recorded the same rank - suggesting that both internal and external factors have a significant influence on project delivery. Overall, the five most critical factors were found to be: 'design changes during construction', 'availability of materials', 'appropriateness of management strategy', 'competence and experience of the project management team' and 'adequacy of information in the tender stage'. Among these, two pairs of factors relate to the scope of work and the project management categories, while one relates to procurement.

In contrast, the results indicated that factors related to project characteristics have less influence because they are part of the project and, subsequently, must be managed to minimise their impact from the early stages of projects. For that reason, factors such as manager experience, management strategy and appropriate risk assessment present a higher level of influence considering that they will have the responsibility to control and mitigate the influence of factors with less influence.

A transparent project definition stage - particularly the sharing of available information on project risk among all parties, provision of complete and clear information about the scope of work, proper coordination between the key stakeholders, and the institution of auditable planning procedures - will reduce project complexity and allow the development of realistic schedules and budgets. This in turn will potentially translate into better performance in project execution. 


\section{Accepted manuscript doi: 10.1680/jmapl.17.00005}

To have a better chance of successfully delivering a megaproject, the project management leadership team must be multi-disciplinary, with expertise in areas such as finance, stakeholder management, integration, human resources management, communication and procurement.

While the present study did not examine the impact of corruption comprehensively, it confirmed the results of previous research, which indicate the importance of addressing corruption. However, to avoid claims and counter claims in future projects, and as seen with the Reficar Modernization and Expansion Project, relevant government agencies must take adequate control and provide early and timely supervision to prevent unwarranted claims by either party at any time. In addition, risk analysis must start at the planning phase and project risks must be shared transparently and responsibly at every stage.

Although the research involved professionals working on megaprojects in Colombia, the variables investigated are of general application to other projects. Hence, the outcome may be of general application by project management professionals, especially where the country dynamics are similar.

Finally, the research demonstrated the application of an appropriate analytical approach to qualitative data as outlined in the aims, in part to highlight the misnomer in some earlier studies that examined critical success factors in specific countries where inferential statistics and non-parametric statistics were wrongly applied to nominal and ordinal data. 


\section{Accepted manuscript \\ doi: 10.1680/jmapl.17.00005}

\section{References}

Ahmed, A. and Othman, E., 2013. Challenges of mega construction projects in developing countries. Organization, Technology and Management in Construction, 5(1), pp.730-746.

Alias, Z., Zawawi, E. and Yusof, K., 2014. Determining Critical Success Factors of Project Management Practice: A conceptual framework. Procedia - Social and Behavioral Sciences, 153, pp.61-69. Available at: 〈http://dx.doi.org/10.1016/j.sbspro.2014.10.041〉.

Altshuler, Alan and Luberoff, David, 2003. Mega-Projects: The Changing Politics of Urban Public Investment. Brookings Institution Press.

Anderson, S., Molenaar, K., and Schexnayder, C., 2006. Final Report for National Cooperative Highway Research Program (NCHRP), Report 574: Guidance for Cost Estimation and Management for Highway Projects During Planning, Programming and Preconstruction. Web-only document. Available at: 〈http://nap.edu/14014〉.

Aziz, R.F., 2013. Ranking of delay factors in construction projects after the Egyptian revolution. Alexandria Engineering Journal, 53(3), pp.387-406.

Cepeda, D.M., 2016. Delivery of mega projects in Colombia on time and according to budget from the contractor's perspective. (Master's thesis). Loughborough University 2015-2016 Baccarini, D. and Collins, A. 2003. "Project Success-A Survey." Journal of Construction Research, 5 (2): 211-231.

Journal of Construction Research, 5 (2): 211-231. BNamericas, 2016. Mega Projects Latin America [online]. Available at: <https://www.bnamericas.com/en/project-profile> (accessed 15 January 2017). 


\section{Accepted manuscript doi: 10.1680/jmapl.17.00005}

Bruzelius, N., Flyvbjerg, B., and Rothengatter, W. 2002. Big decisions, big risks. improving accountability in mega projects. Transport Policy, 9(2), 143-154.

Callegaro, M., Manfreda, K. and Vehovar, V., 2015. Web Survey Methodology. Los Angeles: Sage Publications.

Chan, D.W. and Kumaraswamy, M.M., 1996. A comparative study of causes of time overruns in Hong Kong construction projects. Int J Project Manage, 15(1), pp.55-63.

Cleland, D.I. and King, W.R., 1968. Systems Analysis and Project Management. New York: McGraw-Hill.

Creswell, J.W., 2003. Research Design: Qualitative, Quantitative and Mixed Methods Approaches (2nd ed). Los Angeles: Sage Publications.

Denzin, N., 1970. The research act: a theoretical introduction to sociological method. Chicago: Aldine.

Dimitriou, H.T., Ward, E.J. and Wright, P.G., 2013. Mega transport projects - beyond the 'iron triangle': Findings from the OMEGA research programme. Progress in Planning, 86, $1-43$.

Ejaz, N., Hussain, J., Shabbir, F., Shamim, M.A., Naeem, U.A., Tahir, M.F., Ahmad, N. and Farooq, Q.U., 2013. Assessment of most critical success factors for mega construction projects in Pakistan. Life Science Journal, 10, (10s), pp.255-261

Flyvbjerg, B., 2014. What You Should Know About Megaprojects and Why: An Overview. Project Management Journal, 45(2), pp.6-19.

Haidar, A. and Ellis, R. D. 2010. "Analysis and improvement of megaprojects performance." 


\section{Accepted manuscript doi: 10.1680/jmapl.17.00005}

Proceedings of Engineering Project Organizations Conference, South Lake Tahoe, California, United States.

Hasson, F., Keeney, S. and McKenna, H., 2000. Research guidelines for the Delphi survey technique. Journal of Advanced Nursing 32(4), 1008-1015.

Hauswirth, D.B., Hoffman, D.M., Kane, J.F., Ozobu, I.L., Thomas, C.L. and Wong, P.W., 2004. Collaborative Leadership: Success Stories in Transportation Mega Projects. A 'Lessons Learned' Approach to Collaborative Leadership in Mega Project Management. University of Maryland University College. Available at: http://www.fhwa.dot.gov/ipd/pdfs/collaborative.pdf (accessed 7 August 2012).

Hill, K.Q. and Fowles, J., 1975. The methodological worth of the Delphi forecasting technique. Technological Forecasting and Social Change, 7, 179-192.

Howsawi, E., Eager, D., Bagia, R. and Niebecker, K., 2014. The four-level project success framework: application and assessment. Organisational Project Management, 1(1), p.1. Available at: 〈http://dx.doi.org/10.5130/.v1i0.3865>

Jergeas, G.F., 2008. Analysis of the Front-End Loading of Alberta Mega Oil Sands Projects. Project Management Journal, December, 95-104.

Jergeas, G.F. and Ruwanpura,, J. 2010. Why Cost and Schedule Overruns on Mega Oil Sands Projects? Practice Periodical on Structural Design and Construction 15(1).

Kenny, C., 2007. Construction, Corruption, and Developing Countries. Washington, DC: World Bank Group, pp.2-31.

Li, H. and Guo, H., 2011. Special issue on 'Complexities in managing mega construction 


\section{Accepted manuscript doi: 10.1680/jmapl.17.00005}

projects'. International Journal of Project Management, 29, pp.795-796.

Locatelli, G., Littau, P., Brookes, N.J. and Mancini, M., 2014. Project characteristics enabling the success of Megaprojects: an empirical investigation in the energy sector. Procedia Social and Behavioural Sciences, 119, pp.625-634.

Lopez, C.and Shane, J.S., 2014. Keys to Success in Megaproject Management in Mexico and the United States: Case Study. Journal of Construction Engineering and Management, 140(4), pp.1-7.

Maylor, H. and Blackmon, K., 2005. Researching business and management. New York: Palgrave Macmillan.

Merrow, E.W., 2011, Industrial megaprojects: concepts, strategies, and practices for success, John Wiley \& Sons, Inc., Hoboken, New Jersey.

Miller, R. and Hobbs, B., 2005. Governance regimes for large complex projects. Project Management Journal, 36(2), pp.42-50.

Miller, R. and Hobbs, B., 2009. The complexity of decision-making in large projects with multiple partners: Be prepared to change. In T. Williams, K. Samset and K. Sunnevåg (eds.), Making essential choices with scant information Basingstoke, UK: Palgrave MacMillan, pp.375-389.

Mišić, S. and Radujković, M., 2015. Critical Drivers of Megaprojects Success and Failure. Procedia Engineering, 122(Orsdce), pp.71-80. Available at: <http://linkinghub.elsevier.com/retrieve/pii/S1877705815030982>.

Morris, P.W.G., 1994. The Management of Projects. Thomas Telford, London 


\section{Accepted manuscript doi: 10.1680/jmapl.17.00005}

Morris, P.W.G., 2013. Reconstructing Project Management. John Wiley and Sons, Sussex, UK

Patterson, M.E. and Williams, D.R., 2002. Collecting and analyzing qualitative data: hermeneutic principles, methods, and case examples. Champaign, Illinois: Sagamore Publishing.

Pinto, J.K. and Winch, G., 2015, The unsettling of 'settled science:' The past and future of the management of projects. International Journal of Project Management,34(2), pp.237-245.

Pinzon et al., 2015. Refinería De Cartagena, Lecciones Aprendidas y No Aprendidas De Un Megaproyecto Aprendidas Introducción, Bogota.

Richard, J., 2006. Financing Mega Projects. Public Roads, 69(4). Available at: <http://www.fhwa.dot.gov/publications/publicroads/06jan/02.cfm>.

Riley, M., Wood, R.C., Clark, M.A., Wilkie, E. and Szivas, E., 2000. Researching and writing dissertations in business and management. London: Thomson Learning.

S\&P Global, 2017. Can Colombia's 4G Toll Road Concession Program Shift to a Faster Lane? Ratings. Available at: <www. standardandpoors.com/ratingsdirect> (accessed 25 July 2017).

Sanvido, V., Grobler, F., Parfitt, K., Guvenis, M. and Coyle, M., 1992. Critical success factors for construction projects. Journal of Construction Engineering and Management, 118(1), pp.94-111.

Semana, 2016. Reficar: ¿el escándalo económico del siglo? Semana. Available at: <http://www.semana.com/economia/articulo/reficar-las-irregularidades-por- 


\section{Accepted manuscript \\ doi: 10.1680/jmapl.17.00005}

sobrecostos/458610>.

Shehu, Z., Endut, I. R., Akintoye, A., and Holt, G. D. 2014. Cost overrun in the Malaysian construction industry projects: A deeper insight. International Journal of Project Management, 32(8), 1471-1480. DOI: 10.1016/j.ijproman.2014.04.004

The WorldFolio, 2016. Colombia thinks big with $\$ 70$ billion infrastructure. Available at: $<$ http://www.theworldfolio.com/news/colombia-thinks-big-with-70-billion-infrastructureprogram/3959/> (accessed 23 January 2017).

Transportation Research Board (TRB), National Research Council and National Academy of Engineering. 2003. Completing the "Big Dig": Managing the Final Stages of Boston's Central Artery/Tunnel Project. Washington, DC: The National Academies Press. https://doi.org/10.17226/10629.

Willis, J.W., 2007. Foundations of qualitative research: interpretive and critical approaches. London: SAGE.

World Bank, 1996. Evaluation results 1994. Washington, DC: International Bank of Reconstruction and Development.

Yong, Yee Cheong, and Mustaffa, Nur Emma, 2017. Critical Success Factors for Malaysian Construction Projects: An Investigative Review. International Journal of Built Environment and Sustainability, [S.1.], 4(2). Available at: doi:http://dx.doi.org/10.11113/ijbes.v4.n2.180 (accessed 26 June 2017)

Yong, C., and Mustaffa, E., 2012. Analysis of factors critical to construction project success in Malaysia. Engineering, Construction and Architectural Management, 19(5), pp.543-556. 


\section{Accepted manuscript doi: 10.1680/jmapl.17.00005}

Table 1. Key megaprojects in Colombia

\begin{tabular}{|c|c|c|c|}
\hline Project Name & Sector & $\begin{array}{l}\text { Initial cost } \\
\text { estimate (million } \\
\text { US\$) }\end{array}$ & $\begin{array}{l}\text { Year of completion } \\
\text {-Stage }\end{array}$ \\
\hline El Dorado II International Airport & Airport & 1,000 & 2021 - Early design \\
\hline Magdalena River Navigation Project & Canal & 2,500 & TBD - Early design \\
\hline Ituango Hydro & Electric power & 5,500 & 2019 - Construction \\
\hline Ruta del Sol Highway Sector 2 & Highway & 1,896 & 2017 - Construction \\
\hline Meta Highway Network & Highway & 1,355 & 2020 - Construction \\
\hline Pacifico Highway 1 & Highway & 1,100 & 2020 - Construction \\
\hline Canafisto Hydro Plant & Hydroelectric & 5,000 & $2020-\mathrm{EIA}^{* *}$ \\
\hline Porce III Hydro Plant & Hydroelectric & $1,330^{*}$ & 2011 - Operational \\
\hline El Quimbo Hydro & Hydroelectric & 1,231 & 2015 - Post construction \\
\hline Porce IV Hydro Plant & Hydroelectric & 1,100 & 2015 - Construction \\
\hline Bogota Metro Line No. 1 & Metro & 7,500 & 2022 - Early design \\
\hline Reficar Modernization and Expansion Project & Oil \& Gas & $8,016^{*}$ & 2016 - Operational \\
\hline Pacific Pipeline (OAP) & Oil \& Gas & 5,000 & $2018-\mathrm{EIA}^{* *}$ \\
\hline Oluoducto Bicentenario Pipeline Phases $2 \& 3$ & Oil \& Gas & 4,300 & TBD - Early design \\
\hline Barrancabermeja Refinery Modernization & Oil \& Gas & 3,390 & 2017 - Construction \\
\hline Phase 1 Oleoducto Bicentenario Pipeline & Oil \& Gas & $1,600^{*}$ & 2013 - Operational \\
\hline Carare Railway Network & Rail & 1,536 & TBD - Early design \\
\hline Bogota Light Rail & Rail & 1,145 & 2019 - Early design \\
\hline Darien International Port & Sea Port & 1,000 & TBD - Early design \\
\hline
\end{tabular}

Data source: BNamericas (2016), available at: 〈https://www.bnamericas.com/en/project-profile>

* Final cost estimate, but not including financing cost

** EIA - Environmental Impact Assessment 


\section{Accepted manuscript doi: 10.1680/jmapl.17.00005}

Table 2. Critical success factors investigated

\begin{tabular}{|c|c|c|c|}
\hline Category & Location & $\begin{array}{l}\text { Factors in the planning phase (project } \\
\text { definition) }\end{array}$ & $\begin{array}{l}\text { Factors in the execution phase } \\
\text { (project delivery) }\end{array}$ \\
\hline $\begin{array}{l}\text { 1. Project } \\
\text { characteristics }\end{array}$ & External & $\begin{array}{l}\text { 1. Adverse weather conditions } \\
\text { 2. Project location } \\
\text { 3. Project type } \\
\text { 4. Nature of stakeholders } \\
\text { 5. Duration }\end{array}$ & $\begin{array}{l}\text { Appropriate weather conditions } \\
\text { Project location } \\
\text { Project type } \\
\text { Nature of stakeholders } \\
\text { Duration }\end{array}$ \\
\hline 2. Scope of work & Internal & $\begin{array}{l}\text { 6. Clear scope of work } \\
\text { 7. Adequacy of tender } \\
\text { information }\end{array}$ & $\begin{array}{l}\text { 23. Design changes during } \\
\text { construction }\end{array}$ \\
\hline $\begin{array}{l}\text { 3. Planning and } \\
\text { scheduling }\end{array}$ & Internal & $\begin{array}{l}\text { 8. Realistic work schedule } \\
\text { 9. Appropriate risk assessment }\end{array}$ & $\begin{array}{l}\text { 24. Periodic update of work } \\
\text { schedule }\end{array}$ \\
\hline $\begin{array}{l}\text { 4. Cost } \\
\text { management }\end{array}$ & Internal & 10. Realistic cost estimates & $\begin{array}{l}\text { 25. Regular budget update } \\
\text { 26. Cost control }\end{array}$ \\
\hline \multirow[t]{3}{*}{$\begin{array}{l}\text { 5. } \\
\text { Stakeholder } \\
\text { relationship and } \\
\text { communication }\end{array}$} & $\begin{array}{l}\text { Internal and } \\
\text { external }\end{array}$ & $\begin{array}{l}\text { 11. Transparency and trust } \\
\text { 12. Collaboration }\end{array}$ & $\begin{array}{l}\text { Transparency and trust } \\
\text { collaboration }\end{array}$ \\
\hline & Internal & $\begin{array}{l}\text { 13. Timely and adequate } \\
\text { communication }\end{array}$ & $\begin{array}{l}\text { Timely and adequate } \\
\text { communication }\end{array}$ \\
\hline & External & & $\begin{array}{l}\text { 27. Ability of client to manage the } \\
\text { main contractor }\end{array}$ \\
\hline \multirow[t]{2}{*}{ 6. Procurement } & Internal & $\begin{array}{l}\text { 14. Proper procurement } \\
\text { scheduling }\end{array}$ & \\
\hline & External & & $\begin{array}{l}\text { 28. Availability of materials } \\
\text { 29. Reliability of supplier }\end{array}$ \\
\hline
\end{tabular}




\section{Accepted manuscript doi: 10.1680/jmapl.17.00005}

\begin{tabular}{|c|c|c|c|c|}
\hline 7. & $\begin{array}{l}\text { Project } \\
\text { management }\end{array}$ & Internal & $\begin{array}{l}\text { 15. Management strategy } \\
\text { 16. Competence and experience } \\
\text { 17. Support of top management } \\
\text { 18. Clear organisation structure }\end{array}$ & $\begin{array}{l}\text { Management strategy } \\
\text { Competence and experience } \\
\text { Support of top management } \\
\text { Clear organisation structure } \\
\text { 30. Sub-construction and supplier } \\
\text { management }\end{array}$ \\
\hline 8. & $\begin{array}{l}\text { Construction } \\
\text { process }\end{array}$ & Internal & & $\begin{array}{l}\text { 31. Site management and } \\
\text { supervision } \\
\text { 32. Control of site resources } \\
\text { 33. Coordination and } \\
\text { communication } \\
\text { 34. Method of construction }\end{array}$ \\
\hline 9. & Labour & Internal & $\begin{array}{l}\text { 19. Labour productivity } \\
\text { 20. Availability of skilled labour } \\
\text { 21. Relevance of prior experience }\end{array}$ & $\begin{array}{l}\text { Labour productivity } \\
\text { Availability of skilled labour } \\
\text { Relevance of prior experience }\end{array}$ \\
\hline & & External & 22. Availability of skilled labour & Availability of skilled labour \\
\hline
\end{tabular}




\section{Accepted manuscript doi: 10.1680/jmapl.17.00005}

Table 3. Characteristics of the questions in the survey

\begin{tabular}{|c|c|c|c|}
\hline Round 1 & Objective & Type & Scale \\
\hline $\begin{array}{l}\text { Q1. Please select the total cost range of the } \\
\text { largest megaproject in which you have } \\
\text { participated? }\end{array}$ & Identification & Categorical & $\begin{array}{l}\text { Nominal list of cost ranging from } \\
\text { US } \$ 1 \text { billion to US } \$ 8 \text { billion and } \\
\text { above }\end{array}$ \\
\hline Q2. In which sector was the project? & Identification & Categorical & $\begin{array}{l}\text { Nominal list of the sectors including } \\
\text { industrial processes, transportation, } \\
\text { building, oil and gas, and the } \\
\text { environment }\end{array}$ \\
\hline $\begin{array}{l}\text { Q3. How many years of experience do you } \\
\text { have in megaprojects? }\end{array}$ & Identification & Rating & $\begin{array}{l}\text { Ordinal scale of years in bands } \\
\text { comprising } 1-4 \text { years, } 5-10 \text { years, } \\
11-20 \text { years and more than } 20 \text { years }\end{array}$ \\
\hline Q4. What was your role on the project? & Identification & Categorical & Nominal list of functions \\
\hline $\begin{array}{l}\text { Q5. Please indicate your opinion about the } \\
\text { level of influence of the } 34 \text { factors listed } \\
\text { in the nine categories below based on } \\
\text { your perception of how they might be } \\
\text { critical to the success of megaprojects. }\end{array}$ & Validation & Rating & $\begin{array}{l}\text { Ordinal unipolar comprising four } \\
\text { labels as follows: 'Minimum } \\
\text { Influence', 'Medium Influence', } \\
\text { 'Strong Influence' and 'Extreme } \\
\text { Influence' }\end{array}$ \\
\hline
\end{tabular}




\section{Accepted manuscript \\ doi: 10.1680/jmapl.17.00005}

Table 4. Distribution of respondents by years of experience, project cost, field of expertise and industry

\begin{tabular}{lll}
\hline Description & $\begin{array}{l}\text { Number or } \\
\text { respondents }\end{array}$ & $\begin{array}{l}\text { Proportion to total number of } \\
\text { respondents }\end{array}$ \\
\hline 1-4 years' experience with megaprojects & 22 & $46 \%$ \\
$4-10$ years' experience with megaprojects & 21 & $44 \%$ \\
$10-20$ years' experience with megaprojects & 4 & $8 \%$ \\
$>$ 20 years' experience with megaprojects & 1 & $2 \%$ \\
\hline & 48 & $100 \%$ \\
\hline Cost of project less than US $\$ 4$ billion & 5 & $13 \%$ \\
Cost of project between US $\$$ and 6 billion & 11 & $23 \%$ \\
Cost of project between US $\$ 6$ and 8 billion & 12 & $25 \%$ \\
Cost of project more than US $\$ 8$ billion & 20 & $40 \%$ \\
\hline & 48 & $100 \%$ \\
\hline Site supervision professionals & 12 & $25 \%$ \\
Other professionals & 11 & $23 \%$ \\
Project control professionals & 11 & $23 \%$ \\
Planning professionals & 5 & $11 \%$ \\
Design and engineering professionals & 4 & $8 \%$ \\
Safety professionals & 3 & $6 \%$ \\
Project management professionals & 2 & $4 \%$ \\
\hline & 48 & $100 \%$ \\
\hline Megaproject experience in oil and gas industry & 43 & $89.6 \%$ \\
Megaproject experience in transportation & 3 & $6.3 \%$ \\
Megaproject experience in industrial processes & 2 & $4.2 \%$ \\
\hline & 48 & $100 \%$ \\
\hline & &
\end{tabular}




\section{Accepted manuscript \\ doi: 10.1680/jmapl.17.00005}

Table 5. Respondents views and relative ranking of critical success factors

\begin{tabular}{|c|c|c|c|c|c|c|c|}
\hline \multirow{2}{*}{ Category } & \multirow{2}{*}{ Factor } & \multicolumn{4}{|c|}{ Score } & \multirow{2}{*}{$\begin{array}{l}\text { Mean } \\
\text { score }\end{array}$} & \multirow{2}{*}{$\begin{array}{c}\text { Relative } \\
\text { rank }\end{array}$} \\
\hline & & 1 & 2 & 3 & 4 & & \\
\hline \multirow{5}{*}{$\begin{array}{l}\text { Project } \\
\text { characteristics }\end{array}$} & Number of stakeholders involved & 1 & 8 & 25 & 14 & 3.08 & 1 \\
\hline & Type of project & 6 & 8 & 19 & 15 & 2.90 & 2 \\
\hline & Adverse weather conditions & 1 & 16 & 21 & 10 & 2.83 & 3 \\
\hline & Location of the project & 4 & 15 & 20 & 9 & 2.71 & 4 \\
\hline & Duration of the project & 9 & 11 & 15 & 13 & 2.67 & 5 \\
\hline \multirow[t]{3}{*}{ Scope of work } & Design changes during construction & 0 & 4 & 19 & 25 & 3.44 & 1 \\
\hline & Lack of information at the tender stage & 2 & 4 & 15 & 27 & 3.40 & 2 \\
\hline & Clear scope of work & 1 & 9 & 16 & 22 & 3.23 & 3 \\
\hline \multirow{3}{*}{$\begin{array}{l}\text { Planning and } \\
\text { scheduling }\end{array}$} & Realistic work schedule & 0 & 8 & 20 & 20 & 3.25 & 1 \\
\hline & Appropriate risk assessment & 1 & 6 & 23 & 18 & 3.21 & 2 \\
\hline & Periodic schedule update & 1 & 7 & 23 & 17 & 3.17 & 3 \\
\hline \multirow{3}{*}{$\begin{array}{l}\text { Cost } \\
\text { management }\end{array}$} & Realistic estimates & 1 & 2 & 23 & 22 & 3.38 & 1 \\
\hline & Regular budget update & 2 & 3 & 22 & 21 & 3.29 & 2 \\
\hline & Cost control & 1 & 4 & 24 & 19 & 3.27 & 3 \\
\hline \multirow{4}{*}{$\begin{array}{l}\text { Stakeholder } \\
\text { relationship and } \\
\text { communication }\end{array}$} & Competence to manage contractor & 2 & 6 & 15 & 25 & 3.31 & 1 \\
\hline & Communication between parties & 1 & 8 & 19 & 20 & 3.21 & 2 \\
\hline & Collaboration & 0 & 9 & 20 & 19 & 3.21 & 3 \\
\hline & Transparency and trust & 2 & 8 & 19 & 19 & 3.15 & 4 \\
\hline \multirow[t]{3}{*}{ Procurement } & Availability of materials & 0 & 5 & 17 & 26 & 3.44 & 1 \\
\hline & Proper procurement scheduling & 0 & 7 & 19 & 22 & 3.31 & 2 \\
\hline & Reliability of supplier & 0 & 11 & 20 & 17 & 3.13 & 3 \\
\hline \multirow{5}{*}{$\begin{array}{l}\text { Project } \\
\text { management }\end{array}$} & Management strategy & 0 & 3 & 22 & 23 & 3.42 & 1 \\
\hline & Competence and experience & 0 & 5 & 18 & 25 & 3.42 & 2 \\
\hline & Subcontractors and supplier management & 0 & 5 & 24 & 19 & 3.29 & 3 \\
\hline & Support of top management & 0 & 10 & 20 & 18 & 3.17 & 4 \\
\hline & Clear organisation structure & 0 & 9 & 23 & 16 & 3.15 & 5 \\
\hline \multirow{4}{*}{$\begin{array}{l}\text { Construction } \\
\text { process }\end{array}$} & Site management and supervision & 2 & 4 & 18 & 24 & 3.33 & 1 \\
\hline & Coordination and communication & 0 & 7 & 21 & 20 & 3.27 & 2 \\
\hline & Control of site resources & 1 & 5 & 24 & 18 & 3.23 & 3 \\
\hline & Method of construction & 1 & 8 & 27 & 12 & 3.04 & 4 \\
\hline \multirow[t]{4}{*}{ Labour } & Labour productivity & 0 & 6 & 19 & 23 & 3.35 & 1 \\
\hline & Availability of skilled labour & 0 & 6 & 27 & 15 & 3.19 & 2 \\
\hline & Motivation & 0 & 11 & 26 & 11 & 3.00 & 3 \\
\hline & Experience & 1 & 11 & 23 & 12 & 2.92 & 4 \\
\hline
\end{tabular}




\section{Accepted manuscript \\ doi: 10.1680/jmapl.17.00005}

Table 6. Rank order of the critical success factors

\begin{tabular}{|c|c|c|c|}
\hline Factor & Category & Mean & Relativ \\
\hline 1. Design changes during construction & Scope of work & 3.44 & 1 \\
\hline 2. Availability of materials & Procurement & 3.44 & 1 \\
\hline 3. Management strategy & Project management & 3.42 & 3 \\
\hline 4. Competence and experience & Project management & 3.42 & 3 \\
\hline 5. Adequacy of tender information & Scope of work & 3.40 & 5 \\
\hline 6. Realistic estimates & Cost management & 3.38 & 6 \\
\hline 7. Labour productivity & Labour & 3.35 & 7 \\
\hline 8. Site management and supervision & Construction process & 3.33 & 8 \\
\hline 9. Competence to manage contractor & Stakeholder relationship management & 3.31 & 9 \\
\hline 10. Proper procurement scheduling & Procurement & 3.31 & 9 \\
\hline 11. Regular budget update & Cost management & 3.29 & 11 \\
\hline $\begin{array}{l}\text { 12. Subcontractors and supplier } \\
\text { management }\end{array}$ & Project management & 3.29 & 11 \\
\hline 13. Cost control & Cost management & 3.27 & 13 \\
\hline 14. Coordination and communication & Construction process & 3.27 & 13 \\
\hline 15. Realistic work schedule & Planning and scheduling & 3.25 & 15 \\
\hline 16. Clear scope of work & Scope of work & 3.23 & 16 \\
\hline 17. Control of site resources & Construction process & 3.23 & 16 \\
\hline 18. Appropriate risk assessment & Planning and scheduling & 3.21 & 18 \\
\hline 19. Timely and adequate communication & Stakeholder relationship management & 3.21 & 18 \\
\hline 20. Collaboration & Stakeholder relationship management & 3.21 & 18 \\
\hline 21. Availability of skilled labour & Labour & 3.19 & 21 \\
\hline 22. Periodic schedule update & Planning and scheduling & 3.17 & 22 \\
\hline 23. Support of top management & Project management & 3.17 & 22 \\
\hline 24. Transparency and trust & Stakeholder relationship management & 3.15 & 24 \\
\hline 25. Clear organisation structure & Project management & 3.15 & 24 \\
\hline 26. Reliability of supplier & Procurement & 3.13 & 26 \\
\hline 27. Nature of stakeholders involved & Project characteristics & 3.08 & 27 \\
\hline 28. Method of construction & Construction process & 3.04 & 28 \\
\hline 29. Motivation & Labour & 3.00 & 29 \\
\hline 30. Experience & Labour & 2.92 & 30 \\
\hline 31. Type of project & Project characteristics & 2.90 & 31 \\
\hline 32. Adverse weather conditions & Project characteristics & 2.83 & 32 \\
\hline 33. Location of the project & Project characteristics & 2.71 & 33 \\
\hline 34. Duration of the project & Project characteristics & 2.67 & 34 \\
\hline
\end{tabular}




\section{Accepted manuscript doi: 10.1680/jmapl.17.00005}

Table 7. Ranking of the nine categories of factors investigated

\begin{tabular}{llc}
\hline Category of critical success factors (CSFs) & Mean score & Rank \\
\hline Scope of work & 3.36 & 1 \\
Cost Management & 3.31 & 2 \\
Procurement & 3.29 & 3 \\
Project management & 3.29 & 4 \\
Stakeholder relationship and communication & 3.22 & 5 \\
Construction process & 3.22 & 6 \\
Planning and scheduling & 3.21 & 7 \\
Labour & 3.12 & 8 \\
Project characteristics & 2.84 & 9 \\
\hline
\end{tabular}




\section{Accepted manuscript doi: 10.1680/jmapl.17.00005}




\section{Accepted manuscript doi: 10.1680/jmapl.17.00005}

Table 8. Results of CSF ranking along the dimensions of location, category and life cycle

\begin{tabular}{|c|c|c|c|c|c|c|c|c|c|c|}
\hline Location & Categorisation of factor & $\begin{array}{l}\text { Factors in the } \\
\text { planning phase } \\
\text { only }\end{array}$ & $\begin{array}{l}\text { Mean } \\
\text { score }\end{array}$ & Rank & $\begin{array}{l}\text { Factors in the } \\
\text { execution phase only }\end{array}$ & $\begin{array}{l}\text { Mean } \\
\text { score }\end{array}$ & Rank & $\begin{array}{l}\text { Factors common } \\
\text { to planning and } \\
\text { delivery phases }\end{array}$ & $\begin{array}{l}\text { Mean } \\
\text { score }\end{array}$ & Rank \\
\hline \multirow[t]{10}{*}{ Internal only } & Scope of work & $\begin{array}{l}\text { Clear scope of } \\
\text { work }\end{array}$ & 3.23 & 16 & $\begin{array}{l}\text { Design changes during } \\
\text { construction }\end{array}$ & 3.44 & 1 & & & \\
\hline & & $\begin{array}{l}\text { Adequacy of tender } \\
\text { information }\end{array}$ & 3.40 & 5 & & & & & & \\
\hline & Planning and scheduling & $\begin{array}{l}\text { Realistic work } \\
\text { schedule }\end{array}$ & 3.25 & 15 & $\begin{array}{l}\text { Periodic update of work } \\
\text { schedule }\end{array}$ & 3.17 & 22 & & & \\
\hline & & $\begin{array}{l}\text { Appropriate risk } \\
\text { assessment }\end{array}$ & 3.21 & 18 & & & & & & \\
\hline & Cost management & $\begin{array}{l}\text { Realistic cost } \\
\text { estimates }\end{array}$ & 3.38 & 6 & Regular budget update & 3.29 & 11 & & & \\
\hline & & & & & Cost control & 3.27 & 13 & & & \\
\hline & $\begin{array}{l}\text { Stakeholder relationship } \\
\text { and communication }\end{array}$ & & & & & & & $\begin{array}{l}\text { Timely and } \\
\text { adequate } \\
\text { communication }\end{array}$ & 3.21 & 18 \\
\hline & Procurement & $\begin{array}{l}\text { Proper } \\
\text { procurement } \\
\text { scheduling } \\
\end{array}$ & 3.31 & 9 & & & & & & \\
\hline & Project management & & & & $\begin{array}{l}\text { Sub-construction and } \\
\text { supplier management }\end{array}$ & 3.29 & 11 & $\begin{array}{l}\text { Management } \\
\text { strategy }\end{array}$ & 3.42 & 3 \\
\hline & & & & & & & & Competence & 3.42 & 3 \\
\hline
\end{tabular}




\section{Accepted manuscript doi: 10.1680/jmapl.17.00005}

\begin{tabular}{|c|c|c|c|c|c|c|c|}
\hline & & & & & \multicolumn{3}{|l|}{ experience } \\
\hline & & & & & $\begin{array}{l}\text { Support of top } \\
\text { management }\end{array}$ & 3.17 & 22 \\
\hline & & & & & $\begin{array}{l}\text { Clear organisation } \\
\text { structure }\end{array}$ & 3.15 & 24 \\
\hline & \multirow[t]{4}{*}{ Construction process } & $\begin{array}{l}\text { Site management and } \\
\text { supervision }\end{array}$ & 3.33 & 8 & & & \\
\hline & & Control of site resources & 3.23 & 16 & & & \\
\hline & & $\begin{array}{l}\text { Coordination and } \\
\text { communication }\end{array}$ & 3.27 & 13 & & & \\
\hline & & Method of construction & 3.04 & 28 & & & \\
\hline & \multirow[t]{4}{*}{ Labour } & & & & Labour productivity & 3.35 & 7 \\
\hline & & & & & Relevance of prior & 2.92 & 30 \\
\hline & & & & & experience & 3.00 & 29 \\
\hline & & & & & Motivation & & \\
\hline \multirow[t]{8}{*}{ External only } & \multirow[t]{5}{*}{ Project characteristics } & & & & $\begin{array}{l}\text { Adverse weather } \\
\text { conditions }\end{array}$ & 2.83 & 32 \\
\hline & & & & & Project location & 2.71 & 33 \\
\hline & & & & & Project type & 2.90 & 31 \\
\hline & & & & & $\begin{array}{l}\text { Nature of } \\
\text { stakeholders }\end{array}$ & 3.08 & 27 \\
\hline & & & & & Project duration & 2.67 & 34 \\
\hline & \multirow[t]{2}{*}{ Procurement } & Availability of materials & 3.44 & 1 & & & \\
\hline & & Reliability of supplier & 3.13 & 26 & & & \\
\hline & $\begin{array}{l}\text { Stakeholder relationship } \\
\text { and communication }\end{array}$ & $\begin{array}{l}\text { Ability of client to } \\
\text { manage main contractor }\end{array}$ & 3.31 & 9 & Collaboration & 3.21 & 18 \\
\hline
\end{tabular}




\section{Accepted manuscript doi: 10.1680/jmapl.17.00005}

\begin{tabular}{lllll}
\hline $\begin{array}{l}\text { Internal and } \\
\text { external }\end{array}$ & Labour & Availability of & 3.19 & 21 \\
& Skilled labour & & \\
& $\begin{array}{l}\text { Stakeholder relationship } \\
\text { and communication }\end{array}$ & Transparency and & 3.15 & 24 \\
trust & & & \\
\hline
\end{tabular}

